\title{
MOLECULAR MECHANISMS AND BIOLOGICAL IMPORTANCE OF PLASMODIUM FALCIPARUM ERYTHROCYTE ROSETTING
}

\author{
MATS WAHLGREN*; JOHAN CARLSON; HELENA HELMBY; IRIS HEDLUND \& CARL-JOHAN \\ TREUTIGER
}

\begin{abstract}
Departments of Infectious Diseases, Karolinska Institutet, Huddinge Hospital, S-14186 Huddinge and Uppsala University, Akademiska Sjukhuset, Uppsala, Sweden
\end{abstract}

Rosetting, i.e. the spontaneous binding of uninfected to malaria infected erythrocytes and endothelial cytoadherence may hinder the blood flow and lead to severe Plasmodium falciparum malaria. Falciparum isolates obtained from unconscious patients all form rosettes and/or express a significantly higher mean rosetting rate than isolates from patients with uncomplicated malaria. Furthermore, sera of patients with cerebral malaria are devoid of anti-rosetting activity while sera from patients with mild disease carry high levels of anti-rosetting antibodies. The presence of anti-rosetting antibodies also seems important for the efficient interaction of rosetting infected rbc and leukocytes. Two parasite derived rosetting ligands of $\mathrm{Mr} 22 \mathrm{~K}$ and $\mathrm{Mr} 28 \mathrm{~K}$ named "rosettins", have been found on the surface of rosetting infected erythrocytes. CD36 has in at least some strains of parasites been found to function as a rosetting receptor on the uninfected erythrocyte. Heparin disrupts rosettes of $P$. falciparum in vitro and inhibits the sequestration of rosetting cells ex vivo. In conclusion, rosetting seems a crucial factor in the development of cerebral malaria and treatment of patients with anti-rosetting substances might become an effective adjunct in the treatment of severe malaria.

Key words: Plasmodium falcipanum - erythrocyte rosetting - cerebral malaria - surface antigens

The spontaneous binding of uninfected red cells $(\mathrm{rbc})$ to malaria infected rbcs s.c. rosetting has been found to occur with malaria parasites in which sequestration is a prominent characteristics of the infection (Plasmodium falciparum, $P$. fragile, $P$. chabaudi, $P$. coatney; Wahlgren, 1986; Udomsangpetch et al., 1989a; Handunetti et al., 1989; Udomsangpetch et al., 1991; David et al., 1988). Non-sequestering or poorly sequestering parasites like $P$. berghei, $P$. vivax, $P$. knowlesi, $P$. cynomolgi or nonsequestering $P$. falciparum infected erythrocytes, i.e. ring-stages and gametocytes do not form rosettes (Wahlgren, 1986; Handunetti et al. 1989; Howard \& Gilladoga, 1989). Rosetting usually involves binding of a few uninfected erythrocytes to one or two infected rbc (Fig.

This work was supported by grants the UNDP/World Bank/WHO Special Programme for Research and Training in Tropical Diseases, the Rockefeller Foundation, the Swedish Agency for Research Cooperation with Developing Countries (SAREC), the Swedish Medical Research Council and the Maud and Birger Gustavsson Foundation.

+ Corresponding author.
1B) but more than 10 uninfected rbcs are sometimes found adhered to a single infected erythrocyte. Giant rosettes i.e. aggregates of as many as 10-20 infected and 30-50 uninfected rbc can sometimes been seen (Wahlgren et al., 1990; Carlson et al. 1990a). Infected rbc can be stably enriched for the rosetting phenotype on a Ficoll-Isopaque gradient or by cloning of the cells (Udomsangpetch et al., 1989a) in contrast to endothelial cytoadherence which is a more unstable phenotype (Trager, 1990).

Rosetting is widely distributed in malaria endemic areas of the world and has been found to occur with parasites obtained in SouthAmerica (Colombia), Africa (The Gambia, Ghana, Liberia, The Ivory Coast, Uganda, Tanzania) and Asia (Thailand, Sri-Lanka). More than 300 primary isolates have been assayed for the presence of rosetting and the percent rosetting late stage parasites has been found to vary from 0 to more than $100 \%$ (Udomsangpetch et al., 1989a; Handunetti et al., 1989; Wahlgren, et al., 1990a; Hasler et al.; 1990; Carlson et al., 1990a; Ho et al., 1991a). We here describe and discuss recent results obtained 
on the rosetting-phenomenon in our and other laboratories.

ERYTIIROC:YTE ROSETTING, SFQUESTRATION AND CEREBRAL MALARIA

Erythrocytes infected with mature asexual stages of $P$. falciparum are sequestered in the microvasculature and do not normally appear in the peripheral circulation. This sequestration is thought to reflect adhesion of infected erythrocytes to the endothelial lining as well as rosetting (Wahlgren, 1986; Wahlgren et al., 1989; Howard \& Gilladoga, 1989). Interestingly, parasites expressing endholelial cytoadherence only or rosetling as well as cytoadherence have been found to obstruct the blood flow of ex vivo perfused vessels (Raventos-Suarez et al., 1985; Kaul et al., 1991). While cytoadherent parasites gave some inhibition of the blood now, the one seen with rosetting-cytoadherent parasites was much more pronounced (Kaul et al., 1991). The latter parasites were also found to induce large aggregates of rbc in venular junctions as well as focal clusters along the venular wall while parasites
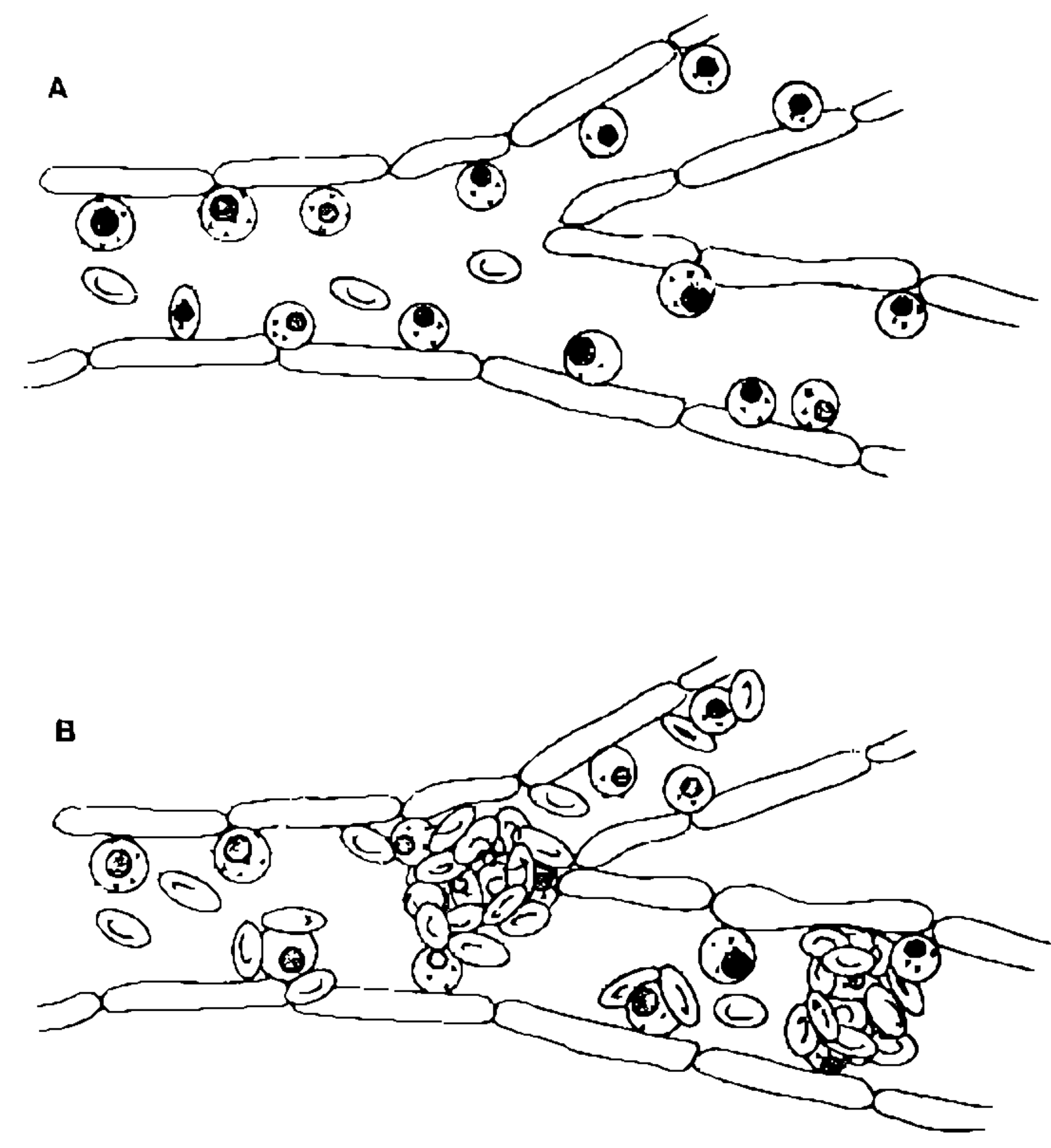

Proposed mecahnisms for sequestration and vessel obstruclion by Plasmodium falciparum infected erythrocytes in the microvasculature depending on the adherence phenolype. Rosetting and endothelial cytoadherence may contribute. independently or in combination, to sequestration of late stage parasites, obstruction of the vessels and the pathogenesis of cerebral malaria. (A) exclusive endothelial cytoadherence and (B) a combination of endothelial cyloadherence and rosetting (adapled from Wahlgren 1986; Cartson et al.. 1990a; Treuliger et al., 1991: Wahlgren. 1991: Kaul et al., 1991). expressing cytoadherence only bound in a diffuse and exclusive manner to the vascular endothelium (Kaul et al., 1991). The rosetting phenotype thus seems to dramatically increase the inhibjtion of the blood flow as compared to merely cytoadherent rbes which suggests a key role for red-to-red cell adhesion in microvascular obstruction in patients with severe malaria (sce also Figure).

We have suggested that rosetting may hinder the blood flow and lead to the development of severe $P$. falciparum malaria (Wahlgren, 1986; Wahlgren et al., 1989; Carlson el al, 1990a; Carlson et al., 1990b; Wahlgren et al., 1990a). In order to test this hypothesis we studied the rosetting rates of parasites as well as the levels of anti-rosetting antibodies in the individual sera from altogether 228 Gambian children. Forty-seven samples were obtained from children with cerebral malaria and one-hundred and sixty-four obtained from children with mild malaria, (Carlson et al., 1990a; Treutiger et al., 1991). All isolates from the children with cerebral malaria were able to form rosettes while those from children with mild forms of the disease either did not form rosettes or had a significantly lower mean rosetting rate. Ho and collaborators also found in a small separate study (Ho et al., 1991 a) that the median rosetting rate of isolates obtained from patients with cerebral malaria was twice that of isolates obtained from patients with uncomplicated disease. Giant rosettes were more frequently formed by isolates from patients with cerebral malaria (Carlson et al., 1990a: Treutiger et al., 1991). 40\% of the sera from patients with cerebral malaria also caused microagglutination of the patients own uninfected and infected rbcs while only $10 \%$ of sera from children with uncomplicated disease caused microagglutination (Treutiger et al., 1991). In contrast, antibodies which disrupt rosettes in vitro were generally absent in the sera of children with cerebral malaria while the sera of children with mild disease frequently contained antirosetting antibodies (Carlson et al. 1990a; Treutiger et al., 1991). Some sera which were devoid of autologous rosette disrupting activity were able to disrupt rosettes formed by other isolates, indicating the presence of different rosetting mechanisms (Treutiger et al., 1991). No correlation was found between the level of binding to melanoma cells and the clinical status of the patient when assaying for binding of infected rbcs to melanoma cells with parasites from some of these patients (Treutiger et al., 1991) which is in line with what has been described by others (Ho et al., 1991b: Marsh et al., 1988). 
Finally, parasites which seem to form rosettes have also been found at autopsy, sequestered in cerebral vessels in patients who died from cerebral malaria (Riganti et al., 1990; Pongponratn et al., 1991). These observations, taken together with the ones above, strongly support the hypothesis that spontaneous rosetting contributes to erythrocyte sequestration and the pathogenesis of cerebral malaria and also suggest that anti-rosetting antibodies confer protection against cerebral disease.

\section{PHYSICO-CHEMICAL CHARACTERISTICS OF RO-} SETTES

Spontaneous rosettes are stable cell aggregates that resist pipetting and centrifugation (Carlson et al., 1990b) but can be disrupted by repeated passage through a needle (Handunetti et al., 1990). The binding is stable at a wide temperature range $\left(41^{\circ} \mathrm{C}\right.$, Carlson et al., 1990b). While rosette formation is independent of the ambient $\mathrm{pH}$ in most strains of parasites ( $\mathrm{pH} \mathrm{6-9;} \mathrm{Helmby}$ et al., unpublished) it has been found to be favoured at a slightly acidic $\mathrm{pH}(6.5-7.1)$ in one parasite strain ( $\mathrm{PAR}^{+} 1$, Carlson et al., 1990b). Addition of chelating agents, which depletes the medium of metal ions, also depletes the cultures of rosettes but this is reversible by adding back an excess of $\mathrm{Ca}^{2+} \mathrm{Mg}^{2+}$ (Carlson et al., 1990b; Helmby et al., unpublished).

Heparin is a negatively charged proteoglycan that effects the blood coagulation system and also inhibits certain cell-to-cell contacts. Heparin was earlier used in the therapy of cerebral malaria but was discontinued due to the occurrence of severe haemorrhages in some patients given the drug (Smitskamp \& Wolthuis, 1971; WHO, 1986). Heparin has been found to disrupt or inhibit rosette formation in vitro, an effect which is immediate and reversible (Udomsangpetch et al., 1989a; Carlson et al., 1990b). However, while rosettes of some isolates are disrupted by the addition of less than $11 \mathrm{U} / \mathrm{ml}$ (Carlson et al., 1990b) most wild isolates are not as sensitive to heparin. E.g. only rosettes of $27 / 54(50 \%)$ freshly isolated Gambian parasites were affected by heparin at a concentration of 10 or $100 \mathrm{IU} / \mathrm{ml}$ but higher concentrations of heparin seem to disrupt rosettes of at least some of the isolates (Carlson et al., submitted). Heparin fractionated for molecular weight and/or affinity for antithrombin III was also tested and we found the anti-rosetting property to be associated with size (high molecular weight) and not with anti-coagulant potential. Thus, a heparin fraction with low affinity for Antithrombin III and thus of a low anticoagulant activity was equally effective in disrupting rosettes as ordinary heparin (Carlson et al., submitted). A combined heparin of high molecular weight and with low antithrombin III affinity (HMW/ LA) exhibited equally good or better anti-rosetting properties than standard heparin while a chemically modified (N-acetylated) HMW heparin fraction, similarly devoid of anticoagulant activity, lacked anti-rosetting potential. Interestingly, heparin of low-affinity also inhibits merozoite invasion in vitro (Butcher et al. 1988; Kulane et al., unpublished). The usefulness of the low affinity heparin fraction in the treatment of severe $P$. falciparum malaria remains to be studied.

TRANSMISSION ELECTRONMICROSCOPY OF ROSETTES

In transmission electron-microscopy the membranes of rosetting, infected and uninfected rbc are found to be closely adhered (Udomsangpetch et al., 1989a). Rosettes formed by merozoites, with what appear to be membrane fragments between the erythrocytes, are sometimes seen (Wahlgren et al., 1990b). The formation of rosettes is independent of the presence of sc. knob protrusions as both knobby and knobless parasites are able to form rosettes (Udomsangpetch et al. 1989a; Berendt et al., 1990; Wahlgren et al. 1990b; Ruangjirachuporn et al., 1991). We have also recently described that a proportion of infected erythrocytes found is fresh isolates are of the knob-less type (Ruangjirachuporn et al., 1991). Out of 60 parasites isolates (almost 600 parasites analyzed) obtained from Gambian patients, cultivated for a single cycle in vitro, 28 were found to contain knobless rbcs as seen by transmission electron microscopy (Ruangjirachuporn et al., 1991). Subtelometric chromosome deletions, including the gene coding for the knob-protein, have earlier been demonstrated to occur in field isolates (Biggs et al., 1989). Moreover, the presence of knobless infected rbc in autopsies or in a primary in vitro culture has previously been described (Corbett et al., 1989; Hommem \& Semoff, 1988). Taken together with the presence of knobless cells in some of the clinical isolates studied by us this indicates that knobless infected rbc are present in nature.

IDENTIFICATION OF THE 'ROSETTINS' ON THE SURFACE OF THE INFECTED ERYTHROCYTE

Rosettes are disrupted when incubated in the presence of trypsin but rosetting reappears after approximately $10 \mathrm{~h}$ if the parasites are returned into in vitro culture (Udomsangpetch et al., 1989a). However the sensitivity of rosettes to tryspin 
varies depending on the strain, thus some parasites are very sensitive to trypsin while others are relatively resistant (Helmby et al., unpublished). Neither chymotrypsin nor neuraminidase have any effects on rosettes. These results indicate a molecule of polypeptide nature to be involved in rosetting and that the binding is independent on the presence of sialic acid (Undomsangpetch et al., 1989a; Carlson et al., 1990b).

Several mono - or polyclonal antibody preparations to different $P$. falciparum or antigens were subsequently tested for their ability to disrupt rosettes. A monoclonal antibody and a polyclona! rabbitserum to PfHRP1/KAHRP/KP were able to dose-dependently disrupt rosettes (Carlson et al., 1990b) while none of the other antibody reagents had any effect on the rosettes including antibodies to related $P$. falciparum or $P$. lophurae histidine rich proteins (PfHRP2, PfHRP3, P1HRP) as well an antibody know to inhibit CD36 dependent cytoadherence in vitro (Udomsangpetch et al., 1989b). The ability of the mouse anti-PfHRP1 antibody to disrupt rosette formation was tested with 56 rosetting fresh Gambian isolates (Carlson et al., 1990a). Approximately 60\% (34/56) of the isolates were affected to some extent by the mAb but only $(5 / 56)$ of the rosetting isolates were completely disrupted. The anti-PfHRPI antibodies reacted with a molecule of $28,000 \mathrm{Da}$ in immunoprecipitation and weakly with a $90,000 \mathrm{Da}$ molecule in immunoblotting (Carlson et al., 1990b). No significant reactivity was seen with normal rbcs. Messenger RNA coding for PfHRP1 has however not be detected in this knobless parasite $(P A R+1)$ and the gene coding for PfHRPl seems to be non-functional (Helmby et al., unpublished). We thus believe the 28,000 Da polypeptide, hereafter named Mr $28 \mathrm{~K}$ 'rosettin', to be the target of our inhibitory antibodies. However, rosettes insensitive to the anti-Mr $28 \mathrm{~K}$ antibodies were recently found to express a distinct rosettin of $\mathrm{Mr}$ $22 \mathrm{~K}$ (Helmby et al., unpublished). Further studies need to be performed in order to characterize the two rosettins and it is not known whether the molecules are located close to or constitute the rosetting ligands themselves.

The polypeptides that mediate adherence of $P$. falciparum infected erythrocytes to the vascular endothelium (PfEMP1 sequestrin, Ag332) are probably distinct from those involved in rosetting as (1) the cytoadherence molecule seems to be a variable, high molecular weight protein (Leech et al., 1984; Ockenhouse et al., 1991), (2) anti-PfHRP1 antibodies will dose-dependently inhibit rosette formation while binding to melanoma cells remains unaffected (Carlson et al., 1990b) and (3) a human monoclonal antibody that inhibits cytoadherence is also known not to affect rosette formation (Udomsangpetch et al., 1989b; Carlson et al., 1990b). Although we have been able to separate cytoadherent and rosetting parasites, these properties are sometimes co-expressed, (Hasler et al., 1990; Ruangjirachuporn et al., 1991). Moreover, binding of infected rbcs to thrombospondin is both heparin sensitive and dependent on the presence of divalent cations (Sherwood et al., 1990). Further work is thus needed to ascertain whether the parasite induced or derived "rosettins" are distinct from those involved in endothelial cytoadherence.

\section{CHARACTERIZATION OF THE RECEPTORS ON THE UNINFECTED ETYTHROCYTE}

In general, little is known about the rosetting receptor(s) on the uninfected erythrocyte but antiCD36 antibodies (OKM5, OKM8) were recently reported to disnupt rosettes formed by the Malayan Camp R ${ }^{+}$strain (Handunetti et al., 1990) a finding which we have confirmed (Helmby et al., unpublished). However, anti-CD36 sensitivity seems rare as rosettes of only two out of nineteen isolates tested by us were found to be disrupted by the anti-CD36 antibody (Helmby et al., unpublished). The capacity of the antibody to disrupt rosettes needs to be further studied to establish the role of $\mathrm{CD} 36$ as an erythrocyte receptor as the antigen is only expressed at low levels on the surface of normal rbcs.

We have speculated that a soluble parasite antigen shed from the infected erythrocytes onto uninfected rbcs might act as a receptor on the uninfected cell (Wahlgren, 1986; Wahlgren et la., 1989). This does not seem to be the case as fresh red cells added to disrupted rosettes are able to participate in rosette formation equally well as rbcs that have been cultured in vitro (Carlson et al., unpublished). However, in giant rosettes there is not always a direct contact between the infected erythrocyte and the uninfected ones a finding that remains to be explained. Thus work remains to be performed in order to clarify the erythrocyte requirements in rosetting and which structures on the uninfected erythrocyte that constitute the common rosetting receptors.

\section{ERYTHROCYTE ROSETTING AND THE IMMUNE- SYSTEM}

Adherence of infected rbc to uninfected erythrocytes (i.e. rosetting), to certain endothelial and 
TABLE I

Parasite - and host - molecules suggested to be involved in rosetting and cytoadherencea

\begin{tabular}{lll}
\hline & $\begin{array}{l}\text { Ligand on } \\
\text { infected erythrocyte }\end{array}$ & Host-receptor \\
\hline Rosetting & $22 \mathrm{~K}$ rosettin & CD36 \\
Cytoadherence & PfEMP1 sequestrin & CD36, TSP, ICAM-1 \\
& $\mathrm{Ag} 332$ & \\
$\mathrm{Band3}$ & \\
\hline
\end{tabular}

a: from references: (Leech et al., 1984; Bamwell et al., 1985; Roberts et al., 1985; Winogrand \& Sherman 1989; Berendt et al., 1989; Carison et al., 1990; Ockenhouse et al., 1991; Helmby et al., unpublished)

TABLE II

Cellular interactions of Plasmodium falciparum infected erythrocytes of different phenotypes with human leukocytes in vitro

\begin{tabular}{llcc}
\hline Straina & Phenotype $b$ & Binding $c$ & Leukocyte aggregationd \\
\hline Palo Alto & $\mathrm{C}^{+} \mathrm{R}-\mathrm{K}-$ & ++ & ++ \\
TM 178 & $\mathrm{C}^{+} \mathrm{R}^{+}$ & ++ & ++ \\
TM 284 & $\mathrm{C}^{+} \mathrm{R}^{+} \mathrm{K}^{+}$ & + & + \\
Palo Alto & $\mathrm{C}-\mathrm{R}^{+} \mathrm{K}^{-}$ & - & - \\
F32 & $\mathrm{C}-\mathrm{R}^{-} \mathrm{K}^{-}$ & - & - \\
\hline
\end{tabular}

Modified from Ruangirachupom et al. (1991).

a: P. falciparum strain.

$b$ : infected red cells showing endothelial cytoadherence $(C)$, sc. surface knobs $(K)$ or rosetting $(R)$.

$c$ : binding of infected toc to peripheral lekuocytes obtained from normal donors.

$d$ : aggregation of leukocytes seen after over night incubation with infected red cells.

melanoma cells as well as to platelets and monocytes has been reported. We recently found that they may also adhere to autologous neutrophils, lympthocytes and plasma cells in fresh clinical isolates (Ruangjirachupom et al., 1991). Binding of infected rbc to leukocytes also induce leukocytes to aggregate. Binding was only found with parasites expressing adherence to melanoma cells in vitro but not with rosetting or non-cytoadherent parasites (Table II). The low degree of binding of rosetting $P$. falciparum strains to leukocytes is probably duo to the fact that the infected rbc are hidden amongst normal erythrocytes and therefore are not recognized by these and other cells. The presence in patients sera antibodies which disrupt rosettes may therefore be instrumental for the interaction with different cells of the immune system and in special for the phagocytosis by monocytes and neutrophil-granulocytes of rosetting infected rbc (Ruangjurachuporn et al., 1991).

\section{CONCLUSIONS}

Rosetting and endothelial cytoadherence may hinder the blood flow and lead to severe $P$. falciparum malaria. In special a strong association has been found to both etythrocyte rosetting and the lack of anti-rosetting antibodies in patients with cerebral malaria. The presence of antirosetting antibodies seems important for the efficient interaction of rosetting infected rbc and leukocytes. The parasite derived or induced molecules on the surface of the infected erythrocytes, which mediate rosetting s.c. 'rosettins', may therefore be important candidates to be included in a malaria vaccine. Furthermore, heparin which disrupts rosettes of $P$. falciparum in vitro and inhibits the sequestration of rosetting cells $e x$ vivo may also have a beneficial effect on the clinical outcome of cerebral malaria. Treatment of patients with anti-rosetting antibodies, in combination with other anti-rosetting substances, might thus become an effective adjunct in the treatment of severe malaria.

\section{REFERENCES}

BARNWELL, J.W.: OCKENHOUSE, C.F. \& KNOWLES, D.M., 1985. Monoclonal antibody OKM5 inhibits the in vitro binding of Plasmodium falciparuminfected erythorytes to monocytes, endothelial and C32 malanoma cells. J. Immunol., 135: 3494-3497. 
BERENDT, A. R., FERGUSON, D. J. P. \& NEWBOLD, C. I., 1990. Sequestration in Plasmodium falciparum malaria: sticky cells and sticky problems. Parasitol. Today, 6: 247-254.

BERENDT, A. R., SIMMONS, D. L., TANSEY, J., NEWBOLD, CI. I. \& MARSH, K., 1989. Intercellular adhesion molecule-1 (ICAM-1) is an endothelial cell adhesion receptor for Plasmodium falciparum. Nature, 341: 57-59.

BIGGS, B. A., KEMP, D. J. \& BROWN, G. V., 1989. Subtelometic chromosome deletions in field isolates of Plasmodium falciparum and their relationship to loss of cytoadherence in vitro. Proc. Natl. Acad. Sci. U.S.A., 86: 2428-2432.

BUTCHER, G.A.; PARISH, C.R. \& COWDEN, W.B., 1988. Inhibition of growth in vitro of Plasmodium falciparum by complex polysaccharides. Trans. $R$. Soc. Trop. of the Royal Society Med. Hyg., 82: 558559.

CARLSON, J.; HELMBY, H.; HILL, A.V.S.; BREWSTER, D.; GREENWOOD, B.M. \& WAHLGREN, M., 1990a. Human cerebral malaria: association with erythrocyte rosetting and lack of anti-rosetting antibodies. The Lancet, 336: 1457-1460.

CARLSON, J.; HOLMQUIST, G.; TAYLOR, D.W.; PERLMANN, P. \& WAHLGREN, M., 1990b. Antibodies to a histidine rich protein (PfHRP1) disrupt spontaneously formed Plasmodium falciparum erythrocyte rosettes. Proc. Natl. Acad. Sci., U.S.A., 87: 2511-2515.

CORBETT, C.E.P.; DUARTE, M.I.S.; LANCELOTTI, C.L.P.; SILVA, M.A.L.G. \& ANDRADE JR, H.F., 1989. Cytoadherence in human falciparum malaria as a cause of respiratory distress. J. Trop. Med. Hyg., 92: 112-120.

DAVID, P.H.; HANDUNNETTI, S.M.; LEECH, J.H.; CAMAGE, P. \& MENDIS, K.N., 1988. Rosetting: A new cytoadherence property of malaria-infected erythrocytes. American J. Trop. Med. Hyg., 38: 289. 297.

HANDUNETTI, S.H.; HASLER, T.H.; VAN SCHRAVENDIJK, M.R. AGUIAR, J.S.; ROTH, E.F.; KAUL, D.K.; NAGEL, R.L. \& HOWARD, R.J., 1990. Rosetting of Plasmodium falciparum malaria: phenotypic diversity in wild isolates, receptor characterization and ex vivo microcirculatory studies. (J.M. Doby Ed.), 1, p. 128. Bulletin de la Sociètè Francaise de Parasitologie.

HANDUNETTI, S.M.; DAVID, P.H.; PERERA, K.L.R.L. \& MENDIS, K.N., 1989. Uninfected erythrocytes form "rosettes" around Plasmodium falciparum infected erythrocytes. Am. J. Trop. Med. Hyg., 40: 115-118.

HASLER, T.; HANDUNETTI, S.H.; AGUIAR, J.C.; VAN SCHRAVENDIJK, M.R.; GREENWOOD, B.M.; LALLINGER, G.; CEGIELSKI, P. \& HOWARD, R.J., 1990. In vitro rosetting, cytoa. dherence, and microagglutination of Plasmodium falciparum -infected erythrocytes from Gambian and Tanzanian patients. Blood, 76: 1845-1852.

HO, M.; DAVIS, T.M.E.; SILAMUT, K.; BUNNAG, D. \& WHITE, N.J., 1991a. Rosette formation of Plasmodium falciparum-infected erythrocytes from patients with acute malaria. Infec. Immunity, 59: 2135 2139.
HO, M.; SINGH, B.; LOOREESUWAN, S.; DAVIS, T.M.E.; BUNNAG, D. \& WHITE, N.J., 199 lb. Clinical correlates of in vitro Plasmodium falciparum cytoadherence. Infec. Immunity, 50: 873-878.

HOMMEL, M. \& SEMOFF, S., 1988. Expression and function of erythrocyte-associated surface antigens in malaria. Biol. Cell, 64: 183-203.

HOWARD, R.J. \& GILLADOGA, A.D., 1989 Molecular studies related to the pathogenesis of cerebral malaria. Blood, 74: 2603-2618.

KAUL, D.K.; ROTH JR., E.F.; NAGEL, R.L.; HOWARD, R.J. \& HANDUNETTI, S.M., 1991. Rosetting of Plasmodium falciparum -infected red cells with uninfected red cells enhances microvascular obstruction under flow conditions. Blood, 78: 812-819.

LEECH, J.H.; BARNWELL, J.W.; MILLER, L.H. \& HOWARD, R.J., 1984. Identification of a strainspecific malarial antigen exposed on the surface of Plasmodium falciparum - infected erythrocytes. J. exp. Med., 159: 1567-1575.

MARSH, K, MARSH, V.M.; BROWN, J.; WHITTLE, H. C. \& GREENWOOD, B.M., 1988. Plasmodium falciparum: The behavior of climical isolates in an in vitro model of infected red blood cell sequestration. Exper. Parasitol, 65: 202-208.

OCKENHOUSE, C.F.; KLOTZ, F.W.; TANDON, N.N. \& JAMIESON, G.A., 1991. Sequestrin: a CD 36 recognition protein on Plasmodium falciparum malaria-infected erythrocytes identified by anti-idiotype antibodies. Proc. Natl. Acad. Sci. U.S.A., 88: 3175 3179.

PONGPONRATN, E.; RIGNATI, M.; PUNPOOWONG, B. \& AIKAWA, M.; 1991. Microvascular sequestration of parasitized erythrocytes in human falciplanum malaria-A pathological study. Am. J. Trop. Med. Hyg., 44: 168-175.

RAVENTOS-SUAREZ, C.: KAUL, D.K.; MACALUSO, F. \& NAGEL, r., 1985. Membrane knobs are required for the microcirculatory obstruction induced by Plasmodium falciparum - infected erythrocytes. Proc. Natl. Acad. Sci. U.S.A., 82: 3829-3822.

RIGANTI, M.; PONGPONRATN, E.; TEGOSHI, T.; LOOAREESUWAN, S.; PUNPOOWONG, B. \& AlKAWA, M., 1990. Human cerebral malaria in Thailand: a clinico-pathological correlation. Immunol., 25: 199-206.

ROBERTS, D.D.; SHERWOOD, J.A.; SPITALNIK, S.L.; PATTON, L.H.; HOWARD, R.J.; DIXIT, V. M., FRAZIER, W.A.; MILLER, L.H. \& GINSBURG, V., 1985. Trombospondin binds falciparum malaria parasitized erythrocytes and may mediate cytoadherence. Nature, 318: 64-66.

RUANGJIRACHUPORN, W.; AFZELIUS, B.A.; HELMBY, H.; HILL, A.V.S.; GREENWOOD, B.M.; BERZINS, K.; PERLMANN, P. \& WAHLGREN, M., 1992. Ultrastructural analysis of fresh Plasmodium falciparum infected erythrocytes and their cytoadherence to human leukocytes. Am. J. Trop. Med. Hyg., 46: 511-519.

SHERWOOD, J.A.; ROBERTS, D.D.; SPITALNIK, S.L.; LAWLER, J.2.; MILLER, L.H. \& HOWARD, R.J., 1990. Falciparum malaria parasitized erythrocytes bind to a carboxy-terminbal thrombospondin fragment and not the amino-terminal heparin-binding region. Mol. Bioch. Parasitol., 40: 173-182. 
SMITSKAMP, H. \& WOLTHUIS, F.H., 1971. New concepts in treatment of malignant tertian malaria with cerebral involvement. Brit. Med. J. I: 714-716.

TRAGER, W., 1990. On the establishment in culture of isolates of Plasmodium falciparum. Trans. $R$. Soc. Trop. Med. Hyg., 84: 466.

TREITUGER, C.J.; HEDLUND, I.; HELMBY, H.; JEPSON, A.; TWUMASI, P. KWIATKOWSKI, D.; CARLSON, J.; GREENWOOD, B.M. \& WAHLGREN, M., 1992. Rosette formation in Plasmodium falciparum isolates and anti-rosetting activity of sera from Gambians with cerebral or uncomplicated malaria. Am. J. Trop. Med. Hyg., 46: 503-510.

UDOMSANGPETCH, R.; WOHLIN, B.; CARLSON, J.; BERZINS. K.; TORII, M.; AIKAWA, M.; PERLMANN, P. \& WAHLGREN, M., 1989a. Plasmodium falciparum -infected erythrocytes form spontaneous erythrocyte rosettes. J. exp. Med. 169: 18351840.

UDOMSANGPETCH, R.; AIKAWA, M.; BERZINS, K.; WAHLGREN, M. \& PERLMANN, P., 1989b. Cytoadherence of knobless Plasmodium falciparum infected erythrocytes and its inhibition by a human monoclonal antibody. Nature (London) 338: 763765.

UDOMSANGPETCH, R.; BROWN, A.E.; SMITH, C.D. \& WEBSTER, H.K., 1991. Plasmodium coatneyi infected erythrocytes form erythrocyte rosettes. $\mathrm{Am}$. J. Trop. Med. Hyg., 44: 399-401.

WAHLGREN, M., 1986. Antigens and antibodies involved in humoral immunity to Plasmodium falciparum. Karolinska Institutet. ISBN-91-7900-026-6.
WAHLGREN, M.; CARLSON, J.; RUANGJIRACHUPORN, W.; CONWAY, D.; HELMBY, H.; PATARROYO, M.E.; MARTINEZ, A. \& RILEY, E., 1990a. Geographical distribution of Plasmodium falciparum erythrocyte rosetting and frequency of rosetting antibodies in human sera. Am. J. Trop. Med. Hyg., 43: 333-338.

WAHLGREN, M.; CARLSON, J.; HOLMQUIST, G.; BERZINS, K; PERLMANN, P. \& AIKAWA, M., 1990b. Erythrocyte rosetting and endothelial cytoadherence in Plasmodium falciparum malaria: implications for vaccine development., p. 467-472. In Vaccines 90. Modem Approaches to New Vaccines Including Prevention of AIDS. Cold Spring Habor Laboratory Press, New York.

WAHLGREN, M.; CARLSON, J.; UDOMSANGPETCH, R. \& PERLMANN, P., 1989. Why do Plasmodium falciparum-infected erythrocytes form spontaneous erythrocyte rosettes? Parasitol. Today, 5: 183-185.

WAHLGREN, M., 1991. Erythrocyte rosetting, sequestration and severe Plasmodium falciparum malaria. Exper. Parasitol., in press.

WHO, 1986. Severe and complicated malaria (World Health Organization Malaria Action Programme). Trans. R. Soc. Trop. Med. Hyg., 80 (Suppl.): 1-50.

WINOGRAD, E. \& SHERMAN, I.W., 1989. Characterization of a modified red cell membrane protein expressed on erythrocytes infected with the human malaria parasite Plasmodium falciparum: Possible role as a cytoadherent mediating protein. J. Cell Biol,m 108: 23-30. 